\title{
Jordanian Foreign Policy in Confrontation with Extremism and Terrorism: The International Alliance Is a Model
}

\author{
Radwan Mahmoud Al-Majali ${ }^{1}$ \& Al-Motasem Ahmad A. Alkhalaileh ${ }^{1}$ \\ ${ }^{1}$ Department of Political Science, Mu’tah University, Jordan \\ Correspondence: Radwan Mahmoud Al-Majali, Department of Political Science, Mu'tah University, Jordan. \\ E-mail: radwanmaj@yahoo.com; naderalsher88@yahoo.com
}

Received: August 10, 2019

doi:10.5539/jpl.v12n4p56
Accepted: September 3, 2019 Online Published: November 28, 2019

URL: https://doi.org/10.5539/jpl.v12n4p56

\begin{abstract}
The study aims at researching in the Jordanian foreign Policy in confrontation with extremism and terrorism through concentration on factors and determinates that pushed Jordan to enter the International Alliance in fighting terrorism, especially fighting $\mathrm{Da}$ 'ish organization. Corresponding to that significance of the study appears through discussing the role of the foreign policy and its instruments in limiting the phenomenon of extremism and terrorism and the most important strategies that the states should follow in light of the internal and external environmental impacts in confronting extremism and terrorism within the preventive procedures and terrorist crises management.

The study employed the method of decision making in achieving objectives of study and its questions where the main question emerged: what are the most important determinants of the Jordanian Foreign Policy in joining the International Alliance against the terrorism, especially fighting the organization of the Islamic State "Da'ish"?

The study deduced a number of results from the most important of them is that: Jordan could take a group of procedures and arrangements at the level of the foreign policy through the period (2011-2017) in confronting extremism ant terrorism within activation of military, diplomatic and media instruments, where the economic instrument appeared from the weakest instruments of the foreign policy and a negative factor in the process of decision-making. The study proved that the joining of Jordan to the International Alliance to fight Dai'sh Organization as a result of great impact of the geographic determinant, and availability of the organization at geographic territories forming a strategic danger on Jordan. The study also recommended with the necessity of treating the social and economic problems as an important side and supporter in enhancing the instruments of the Jordanian Foreign Policy.
\end{abstract}

Keywords: foreign policy, international alliance, extremism and terrorism

\section{Introduction}

The period of the Arab Spring in the year 2011 formed a beginning of the regional instability stage in the region; it witnessed a group of political economic and security changes. Appearance of terrorist organizations crossing the borders had the effective role in increasing the security perceptions of the states, and their political interests in enhancing procedures and arrangements to have barriers against influence of those terrorist groups in the political regimes for the challenge of Extremism and Terrorism had developed in the shadow of existence of instable climate in the Arab region at the acting political, economic and social problems aggravation, so the opportunity was appropriate to exploit the state of occupational dysfunction of the state in enhancing objectives of those organizations and building their abilities in dominating controlling and increasing the numbers of the supporting groups.

On the other part appearance of the Islamic State Organization "Dai'sh" * in the year 2014 and its domination on great area in Iraq and Syria in a haste form, pushed the states, headed by the United States of America to be alert to danger of the organization and the necessity of confronting it, for what it form of impact on the American interests. So, it established the international Alliance of Terrorism in August, 2014 to fight Dai'sh Organization.

\footnotetext{
* Dai'sh or (ISIS) -Islamic State in Iraq and Syria- originated as an independent entity following a split with its parent organization, Al Qaeda during the Syrian Civil War. Sit: http://www.eip.org/en/news-events
} 
The Jordanian Foreign Political perspective in confrontation with extremism and terrorism from one of the functional abilities of the state in accordance with systematical coordination of inputs, processes and outputs for the action of the political regime, that is within the frame of correlation and coordination of the different elements so as to perform different roles for one good, it is prevention and treatment of the extremism and terrorism phenomenon. This thing conspicuously appeared through the Jordanian decision-maker's perception of the necessity of joining the International efforts to fighting extremism and terrorism, where he perceived that ability of Jordan - in light of the limits of His economic possibilities, appears in the International Alliance so, Jordan joining the International Alliance to fight Dai'shs Organization was part the these efforts.

And in the same context, it appears to the researcher in the how of confronting extremism and policy and the how of confronting extremism and terrorism that means of confronting this phenomenon push Jordan to activate the external behaviour through increasing adaptation with influences of the regional and international environment and attempt of finding replacements and alternatives in the process of decision-making, where steps appeared at the level of internal and external policy had been expressed through the governmental procedures that had been taken within the legislative, institutional, and educational frame work to confront the phenomenon of extremism and terrorism, and through the activation of the foreign policy in joining numerous regional and international treaties concerning fighting extremism and terrorism, and participation in numerous international conferences, and military alliances to confront the danger of the terrorist organizations, crossing the borders.

\subsection{Problem of Study}

Instruments of foreign policy play an important role in carrying out trends of the decision-maker, aiming at achieving the higher interests of the state where the international efforts in confronting the phenomenon of extremism and terrorism became one of the main priorities in the foreign policy of the state, especially with intensification of the terrorist organizations, crossing borders danger, which their activation increased inside the world order in the shadow of means of communications and technology development, and increase of the international and non-international armed conflicts state, that led to increase indicators of the international and regional instability state. From this point these developments formed a domain of states concern in activating instruments of foreign policy at a great form especially with emergence of the state of political instability in Iraq and Syria after the year 2011, the thing that shared in the appearance of Dai'sh Organization, and formed danger on the Jordanian National security and interests.

From this point emerges the main question of study: What are the determinants of the Jordanian Foreign policy in confrontation with the extremism and terrorism phenomenon? And how the joining of Jordan to the International Alliance against Dai'sh's Organization in achieving objectives of the Jordanian Policy?

\subsection{Objectives of Study}

The study seeks to pin-point the essence of the Jordanian Foreign Policy towards extremism and terrorism, and the most important roles of the Jordanian Foreign Policy and its steps, especially the Jordanian role in the international Alliance against Dai'sh's Organization and recognizing the most important results, determinants and causes resulted in joining.

\subsection{Significance of Study}

Significance of study springs from its evaluation and analysis of the nature and effectiveness of the Jordanian Foreign Policy in confrontation with the phenomenon of extremism and terrorism, and how to achieve the instruments of foreign policy for the interests of the state and protection of its security, and the how of treating the negativities resulted from the reactions of the internal and external environment from the process of decision-making after the stage of evaluation.

\subsection{Hypothesis of Study}

The study starts from a group of hypotheses, performed on the relationship between two variables: independent and subordinate. (Variable of foreign policy and variable of extremism and terrorism).

1) The more increased of the phenomenon of Extremism and Terrorism, the most increased the effectiveness of the Jordanian Foreign Policy in confronting the danger of this phenomenon.

2) The more increased sharpness of political, economic, security and social problems inside the community. The weakest of the Jordanian external decision-maker alter natives in confronting extremism and terrorism. 


\subsection{Concepts of Study}

\subsubsection{Extremism and Terrorism}

There is no united definition of terrorism, that is because of the difference and multitude of its forms, types and its nature and discrepancy of states on it, for the Geneva Treaty in 1973, concerning repression and punishment of terrorism, defined it as: "Terrorist act" is that directed against a creation state, or meant by it a state of horror in minds of certain persons, or a group of persons, or the common public"1.

Corresponding that extremism is defined that it is "exaggeration in a creed, ideology, thinking, or a certain faith concerning a group, sect, religion, faction, or a certain group expressing a state of getting out of the intellectual and behavioural rules consented by a community of ideas, customs and beliets" ${ }^{\prime 2}$.

\subsubsection{Jordan Politics}

Politics is viewed as management of the state affairs' at the internal and external level ${ }^{3}$.

And the Jordanian politics is defined as "the group of activities and interactions that occur within the Jordanian internal and external behaviour and seeks to achieve objectives and higher interests of the Jordanian state. For the Jordanian internal policy within the limits of the Jordanian Political Regime within the constituent elements of it: from the government, the Parliament, the Judicial Authority, the Political parties, the Public Opinion, the Geographic Location, the Economic System, the Cultural System and the Social System....etc, express interactions and policies occur inside the internal ${ }^{4}$.

Environment, corresponding that the Jordanian foreign Policy forms the pattern of activities and the interactions of the Jordanian external behaviour in his international and regional surrounding at the different issues. And this external behaviour is expressed through the process of decision-making and instruments of its carrying out ${ }^{5}$.

\subsubsection{The Foreign Policy}

It is defined that its activities and its external political behaviour seeking to achieve certain objectives expressing their interests. They have been made and their decisions taken by the responsible institutions it the state, in accordance with texts of their constitutions. The practice of planning right and carrying out the foreign policy is not confined to states, but also there are worldly and regional organizations, powers, and non-governmental organizations and companies with multitude nationalities, they have their goals and policies towards states and international organizations ${ }^{6}$.

\subsubsection{The international Alliance against the Islamic State organization (Dai'sh)}

This alliance was established in September, 2014 led by the United States of America and the participation of twenty states including Jordan, to fight the organization of Dai'sh, and stop its domination on lands in Iraq and Syria. The international Alliance had covered a group of fighting and military actions, most of them concentrate on the air warlike operations ${ }^{7}$.

\section{Previous Studies}

The study depended on a group of previous studies, represented in the following:

1) Al Hajahjah study (2018) "Jordanian Policy in Confrontation with Extremism and Terrorism (2011-2017)" that evidenced the most important steps of the Jordanian policy at the level of internal and external policy in confrontation with the phenomenon of extremism and terrorism. The study had deduced a result with existence of truthful effort by Jordan corresponding existence of obstacles and challenges in front of his role in confrontation with the terrorist organizations.

\footnotetext{
${ }^{1}$ The first article of Geneva Treaty concerning repression and terrorism prevention for the year 1973. \#

${ }^{2}$ Directorate of deliverance of advisory opinions in the Jordanian Armed Forces (2006) extremism its fact and incentives, the General leadership of the Jordanian Armed Force, p.23.

${ }^{3}$ Al Hazaimeh et al (2018) principles of political Science. Dar Konos Al-Ma'refah (Treasures House) Amman, p.12.

${ }^{4}$ Schwedler, J. (2012). The Politics of Protest in Jordan. Foreign Policy Institute Footnotes. The Newsletter of FPRI'S Watchman center, Philadelphia.

${ }^{5}$ Al-Sawadhah, A. (2016). Effect of Regional Changes on the Political Stability in Jordan (2011-2016), Unpublished Master Degree Dissertation, Department of Political science, in Mu'tah University, 2016. P. 34.

${ }^{6}$ Al-Hajahjeh, Sadam (2016) Jordan Politics in confrontation with Extremism and Terrorism in the period (2011-2017) doctorate Dissertation, Dept. of political science, Mu'tah University, Page15.

${ }^{7}$ A'dwan, Ali (2017), The Jordanian Foreign Policy towards the terrorist organizations, crossing borders, a case study of Dai'sh Organization (2011-2016), a doctorate dissertation, dept. of social science, Mu'tah University, Page 67.
} 
2) Al-A'dwan study (2017)'The Jordanian Foreign Policy towards the terrorist organizations crossing the borders: a case study of Dai'sh Organization (2010-2016)".The study made a research in the nature, rules, and determinants of the Jordanian Foreign Policy towards Dai'sh Organization.

3) Mohammad study (2013): "internal and external challenges affecting the Jordan national security in the period of (1999-2013), a case study. The study aimed at analyzing and studying the nature of internal and external challenges that affect the Jordan national security, and shedding light on the administration of the Jordanian State and its competence to deal with these challenges.

\section{Firstly: The Theoretical and Methodological Frame. Work of Study}

The process of decision-making forms the most important processes, through which an appropriate formula of the different substitutes of the group, competitive to achieve goals and avoid unhoped results in them ${ }^{8}$.

From here appears the employment of decision-making theory in the Foreign Policy through studying the how, in which the decision is made, nature of the external environment, size of its influences and the most important affecting determinant.

For the Jordanian Foreign Policy is performed on a group of decision-making departments, in which the king emerges a decision-maker in light of emergence supporting roles in this process: like the role of the Royal Court, the government, the legislative authority and the security institutions...etc ${ }^{9}$.

Negative to what preceded the decision-making in the Jordanian Foreign Policy is characterized with easiness and elasticity, being the process of decision-making is individualized by the King-being head of the executive authority- he makes the foreign policy and takes the important decisions, but the rest of other political departments their role is confined in submitting consultation and execution. The king's role extends to receiving presidents of states and doing external rounds, concluding treaties and international agreements and authorizing them. He is the maker and executor of the foreign policy ${ }^{10}$. The Jordanian Constitution had given a great role to the king in the Jordan foreign policy, and so the process of decision-making is affected by his personality, his leading pattern, his skills, experiences, his cultural background, his religious beliefs and the extent of his perception of the political incidents around him ${ }^{11}$.

The determinants of the internal and external environment affect in the process of the Jordanian external decision -making (it is not possible to talk about Jordanian external policy without observing the internal environment represented in the structure of the Jordanian Political Regime, and the societal factors (economic, cultural, population, educational and geographic...) and the extent of these determinants interaction towards patterns of different issues at a negative or positive form, and the extent of the decision results reflection on the citizen and the different reactions ${ }^{12}$.

The economic, historical, population and geographic factors are considered from the influential factors in the Jordanian Foreign Policy, through which can explain many decisions (like the derision of Jordan joining the International Alliance against terrorism). Without ignoring the external environment within the regional and international frame work ${ }^{13}$.

The talk about the Jordanian Foreign Policy instruments in carrying out trends of the Foreign Policy decisions starts from the nature and determinants of this policy, that is affected by internal and external elements and confronts a group of challenges in their internal and external environment affected in the process of decision making $^{14}$. (Look table 1).

\footnotetext{
${ }^{8}$ Al-Majali, Radwan (2018), The Political Perspective in confrontation with the phenomenon of Extremism and Terrorism: Jordan is a case of study, a work paper submitted in the First International Conference: Towards a National Strategy to Fight Extremism and Terrorism, Faculty of Post graduate Studies, Mu'tah University, pp6-7.

${ }^{9}$ Ryan, Crust R. (2002), Jordan in Transition: From Hussein to Abdullah, Lynne Rienner Publisher, Inc. United Kingdom. PP 68-69.

${ }^{10}$ Tayem, F and Majali, R (2018), “The Arab Spring Crisis and the Democratic Trend in Jordan”, Journal of Political and Law, Vol. 11, No. 3, Canadian Center of Science and Education. Page 114.

${ }^{11}$ Al-Thbeitat, Gasem (2005), Effect of changes in the world order on the Jordan Foreign Policy in the period (1989-200) a doctorate dissertation, Institute of Research and Arab Studies, Cairo, p.69.

${ }^{12}$ Al-Sawadhah, Ibid. pp37-44.

${ }^{13}$ UNDP,(2018)," Support to Counterterrorism, Stabilization, and Counter radicalization in Jordan”, Sit: www.jo.undp.org.

${ }^{14}$ Al-Majali, Radwan (2019), the Jordanian Foreign Policy, memorandums of a subject of seminar in diplomacy for students of Master in the International Relations 2018-2019, pp.45-47.
} 
Table 1. Challenges facing Jordan in confrontation with extremism and terrorism ${ }^{15}$

\begin{tabular}{|c|c|c|c|c|}
\hline $\begin{array}{l}\text { Internal } \\
\text { Determinant }\end{array}$ & $\begin{array}{l}\text { Educational System: } \\
\text { weakness of the } \\
\text { Scientific Research, } \\
\text { Decline of the } \\
\text { Educational and, } \\
\text { weakness of the Arabic } \\
\text { language, } \\
\text { inappropriateness of } \\
\text { Educational outlets with } \\
\text { labour Market, and the } \\
\text { Problems in the } \\
\text { Educational and } \\
\text { Teaching Curriculums. }\end{array}$ & $\begin{array}{l}\text { Political Regime: } \\
\text { legitimacy of the system } \\
\text { of the Government and } \\
\text { the nature of the Political } \\
\text { will and its trends, the } \\
\text { nature of legislations and } \\
\text { the political laws } \\
\text { Systematizing the } \\
\text { Democratic work, and } \\
\text { the Nature of relationship } \\
\text { between the legislative } \\
\text { and Executive Authority } \\
\text { and the sharpness of } \\
\text { Popular Congestion from } \\
\text { the public Policies. }\end{array}$ & $\begin{array}{l}\text { Social System: } \\
\text { Decline of } \\
\text { living-standard and } \\
\text { Increase of Poverty } \\
\text { and Unemployment, } \\
\text { corruption, Mediation } \\
\text { and bias, increase of } \\
\text { crime, problems and } \\
\text { social violence, } \\
\text { tribalism, regionalism } \\
\text { and partisanship. }\end{array}$ & $\begin{array}{l}\text { Economic system: } \\
\text { economic resources } \\
\text { limitsess, Privatization, } \\
\text { Deficit Presupuestario, } \\
\text { deficit of Balance Trade, } \\
\text { Continuous Height of } \\
\text { prices, Increase of } \\
\text { External Indebtedness. } \\
\text { Increase of Depending } \\
\text { on loans and External } \\
\text { Aids, Increase of Taxes } \\
\text { and Fees, and } \\
\text { disappearance of the } \\
\text { Middle Class. }\end{array}$ \\
\hline $\begin{array}{l}\text { External } \\
\text { Determinant }\end{array}$ & $\begin{array}{l}\text { The Palestinian Problem } \\
\text { and state of Regional } \\
\text { Instability }\end{array}$ & $\begin{array}{l}\text { Impact of Donation } \\
\text { parties and International } \\
\text { Economic Foundations } \\
\text { (International Monetary } \\
\text { Fund, the World Bank) }\end{array}$ & $\begin{array}{l}\text { Globalization, worldly } \\
\text { Economic Crises. }\end{array}$ & $\begin{array}{l}\text { The Compulsory } \\
\text { Emigrations of the } \\
\text { Palestinian Refugees in } \\
\text { both years 1948\&1967. } \\
\text { And the Accidental } \\
\text { Emigration after the } \\
\text { second Gulf Crisis in } \\
\text { 1991. The American } \\
\text { Occupation of Iraq, } 2003 \\
\text { and the crisis of the } \\
\text { Syrian Refuge } 2011 .\end{array}$ \\
\hline
\end{tabular}

\section{Secondly: The External Jordanian Steps in Confrontation with Extremism and Terrorism}

The Jordanian decision-maker started a group of steps at the level of Foreign Policy for the sake of enhancing the Jordanian role in fighting extremism and terrorism through the period (2011-2018). This role had appeared through the rising of the Jordanian Political Speech in many occasions including numerous vocabulary about Extremism and Terrorism and effectiveness of the different royal visits, and that became the issue of extremism and terrorism on the agenda of those visits, in addition to the Jordanian formal partnership in the International treaties concerning the fight of extremism, terrorism and participation in conferences, symposiums and International meetings, the military and security participation ... etc. those steps can be summed up as follows ${ }^{16}$ :

1) Jordan signing a number of international treaties to fight terrorism. Jordan signature on the Jordanian American Treaty to fight Dai'sh's propaganda on the Internet of April 11 $1^{\text {th }}, 2016$, signing the Arab Treaty to fight money-washing in the year 2010, the Arab strategy for Media in 2013 and the Treaty of Tension Lowering among Jordan, Russia and the United States of America in the year 2017.

2) Participation of Jordan in the Arab, Islamic, and International Meeting: attending the Arab Summit Conferences through the period (2011-2017), and the most prominent of what came in His Majesty the King's

${ }^{15}$ Al-Majali, Radwan (2015) Impact of Protesting Movements on the Political Stability in Jordan, Journal of Politics and Law Booklet. Algerian University of Gasidi Mirbah, p.45.

${ }^{16}$ Sanchez, V (2018), Lights and Shadows of Jordan's Counterterrorism Strategy, Opinion Document, isee.es .pp 13-19. And, Al-A'dwan, Ali, ibid, pp.141-147. And also, Al-Hajahjeh, Ibid, pp.110-115. 
speech that relates with extremism and terrorism. Attending the Islamic Submit Conference in Istanbul in April, 2016 and the most important decisions in it related with extremism and terrorism, Istanbul last Conference about Jerusalem in 2017. And Participation in the Islamic Summit Conference in Mecca on August 18, 2012 and its most important decisions in what relates with Extremism and Terrorism. And participation in the Arab African Summit in Kuwait on November $20^{\text {th }}, 2013$ and its most important decisions of what relates with Extremism and Terrorism. Participation in the periodical meetings of the United Nations General Assembly (2011-2017) and the Jordan speech in what relates with extremism and terrorism. Participation in the Summit of States participating in the International Alliance to confront extremism and terrorism on September 30 $0^{\text {th }}$, 2015. Participation in London Meeting on January $22^{\text {nd }}, 2015$, and participation in Rome Meeting on March $2^{\text {nd }}, 2016$ and Geneva Meeting on April $7^{\text {th }}, 2016$, concerning fighting extremism. And participation in the American Islamic Summit in Riyadh on May $20^{\text {th }}, 2017$ and its most important decisions towards Extremism and Terrorism.

3) The Mutual Military Maneuveres between Jordan and Arab and Foreign States. Maneuveres of the Combat Ready Lion that started after the year 2011, Maneuveres of the Thunder of the North in Saudi Arabia, 2016, the Jordanian Egyptian Maneuveres in the year 2016, and the Jordanian Saudi Maneuveres in 2017 ... etc.

4) Participation in the International Alliance, Military and Security against Dai'sh's Organization in 2014.

5) Military Participation in the International Alliance against the Hoothies Group in Yemen in the year 2015.

6) The most important Security and Military Procedures done by Jordan to insure the eastern and the northern borders

7) The security and Military procedures taken by Jordan to support the Sunni Tribal Existence in Iraq and Syria near borders with Jordan.

King Abdulla II Bin Al-Hussein's Speeches in the different International Meetings and assuring the necessity of confronting extremism and terrorism. (the King's Speech in New York Summit on September $29^{\text {th }}$., 2015 for the International Alliance against terrorism, and the Kin's speech in the United Nations General Assembly dated September $21^{\text {st }}, 2011$, and the King's Speech in front of the European Parliament on March $10^{\text {th }}, 2015 \ldots$ etc. $)^{17}$.

\section{Thirdly: Jordan Joining the International Alliance to fight Dai'sh's Organization}

Jordan joining the International Alliance against Dai'sh's organization came as a part of the International efforts that Jordan sought to be part of fighting terrorism at the legislative and institutional level, where the participation of Jordan came on September $22^{\text {nd }}$., 2014 and application of the Jordanian Foreign Policy trends in achieving the high interests of the state and keeping Jordanian National Security, especially that Jordan was implied in the thinking of the terrorist organizations, crossing the borders as a legitimate goal and the Jordanian security strategy had depended, since Amman Terrorist Explosions in the year 2005, the necessity of achieving a preventive stroke to the terrorist organizations at their concealments before waiting their danger coming. The participation of Jordan had appeared in the International Alliance througth ${ }^{18}$ :

1) The air-skrokes of the organization targets in Syria and Iraq.

2) Employing a number of the Jordanian bases as a part of the air-operations against the organization.

3) The security and intelligence support to the Alliance forces, and submitting information about locations of the organization and its particular targets.

4) Security coordination with the Iraqi government and depending on the strong relations with the Iraqi Sunni Tribes in West Iraq and East of Syria in their confrontation with the organization.

But the causes that pushed Jordan to join the international Alliance against Dai'sh's organization ${ }^{19}$ :

1) Jordan participation came as a result of his bearance in the period that preceded joining the Syrian crisis precariousnesses, politically, security, economically, and humanly, especially the Syrian Refugees Crisis.

2) Transformation of the northern and Eastern borders of Jordan into a source of anxiety and security threatening of the possibility of the terrorist individuals to exploit .... The case of disturbance and armed conflict to achieve their goals towards Jordan.

\footnotetext{
${ }^{17}$ King Abdullah II Bin Al-Hussein's Site (2018): www.King abdullah.jo.

${ }^{18}$ Thiabat, Kheir (2015), Jordan Participation in the International Alliance to fight Dai'sh's organization, Journal of Strategic Visions, April, pp.50-51.

19 Al-Majali, Radwan (2018) political Perspective in Confronting Extremism ad Terrorism, a work paper submitted to the conference, "the National Strategies in Confronting international Terrorism and Extremism” Held on April 23 ${ }^{\text {rd }}$., 2018, Mu'tah University, pp.15-16.
} 
3) Emergence of the fighting sectic and religious militias in Syria and Lebanon and the possibility of their threatening to Jordan, especially their movements were done near the Jordanian, Iraqi and Syrian borders.

4) Vision of Dai'sh's organization in constituting the concept of caliphate on territories combining all the surrounding states of Syria and Lebanon, and Jordan in particular.

5) The Jihadi Ancestral Trends in Jordan that may form a social incubator for the organization in Jordan ${ }^{20}$.

There upon Jordan joining the International alliance against Dai'sh's organization in the period (2014-2018) had led to a group of procedures could enhance role of Jordan in protecting his Northern and Eastern borders, increase of security coordination between him and the International and Regional parties, be informed of the Jordanian Military abilities in confronting the external threats, and the how of terrorist crises management ${ }^{21}$. Corresponding that the land military operations of the Iraqi forces and the Democratic Syrian Forces in parallel with the strokes of the International Alliance had weakened and fallen the existence of the organization in Raqqa and Mousel, in addition to weakening the organization and confining its extension.

\section{Results of Study}

The study deduced a group of results:

1) Participation of Jordan in the International Alliance against the organization of Dai'sh within the Jordanian efforts in protecting interests of the state and guarantee of its security safety, and influence of the geographic factor as one of the effective factors in the process of Jordanian external decision-making. For the effectiveness of the Jordanian Foreign Policy increased in the period that followed the appearance of Dai'sh's organization in the year 2014, especially after the Dai'sh's organization captivation of the Jordanian pilot Moa'th Al-Kasasbeh and burning him, where the foreign policy appeared within two levels:

3) The first level: the security and military level.

4) The second level: the political and diplomatic level.

2) There is a group of challenges that affected the effectiveness of the Jordanian Foreign Policy represented, at the internal level, in the state of social and economic instability, and at the external level, in the regional instability and the crisis of the Syrian Refuge, for the external determinants appeared as an effective factor at a great deal in increasing its impact in the process of decision-making in the Jordanian Foreign Policy more than the impact of the internal determinants.

3) The results of Jordan joining the International Alliance for fighting the Organization of Dai'sh, showed being informed of the Jordanian military ability, and the degree of security and political coordination in dealing with crises and external threats, and the success of the International Alliance forces in confining the enlargement of the organization extension, and success in restoring a great area of lands dominated by the Organization after the year 2014 .

\section{References}

A'dwan, A. (2017). The Jordanian Foreign Policy towards the terrorist organizations, crossing borders, a case study of Dai'sh Organization (2011-2016), a doctorate dissertation, dept. of social science, Mu'tah University.

Al Hazaimeh et al. (2018). Principles of political Science. Dar Konos Al-Ma'refah (Treasures House) Amman.

Al-Hajahjeh, S. (2016). Jordan Politics in confrontation with Extremism and Terrorism in the period (2011-2017) doctorate Dissertation, Dept. of political science, Mu'tah University.

Al-Majali, R. (2015). Impact of Protesting Movements on the Political Stability in Jordan. Journal of Politics and Law Booklet. Algerian University of Gasidi Mirbah.

Al-Majali, R. (2018a). Political Perspective in Confronting Extremism ad Terrorism, a work paper submitted to the conference, "the National Strategies in Confronting international Extremism and Terrorism" Held on April $23^{\text {rd }}$. , 2018, Mu'tah University.

Al-Majali, R. (2018b). The Political Perspective in confrontation with the phenomenon of Extremism and Terrorism: Jordan is a case of study, a work paper submitted in the First International Conference: Towards a National Strategy to Fight Extremism and Terrorism, Faculty of Post graduate Studies, Mu'tah University.

\footnotetext{
${ }^{20}$ The Jordanian Newspaper "alrai". An essay entitled Experts and politicians participation of Jordan in the Alliance against terrorism is a necessary step to protect the National Security. Dated October, 2nd, 2014. http://alraia.com/article/67960.html

${ }^{21}$ Hussein, R (2016),"Jordan’s Approach to Counter-Extremism “, Friedrich-Ebert-Stiftung Jordan and Iraq. P 95.
} 
Al-Majali, R. (2019). The Jordanian Foreign Policy, memorandums of a subject of seminar in diplomacy for students of Master in the International Relations 2018-2019.

Al-Sawadhah, A. (2016). Effect of Regional Changes on the Political Stability in Jordan (2011-2016), Unpublished Master Degree Dissertation, Department of Political science, in Mu'tah University.

Al-Thbeitat, G. (2005), Effect of changes in the world order on the Jordan Foreign Policy in the period (1989-200) a doctorate dissertation, Institute of Research and Arab Studies, Cairo.

Directorate of deliverance of advisory opinions in the Jordanian Armed Forces. (2006). Extremism its fact and incentives, the General leadership of the Jordanian Armed Force.

Hussein, R. (2016). Jordan's Approach to Counter-Extremism. Friedrich-Ebert-Stiftung Jordan and Iraq.

King Abdullah II Bin Al-Hussein's Site. (2018). Retrieved from www.King abdullah.jo

Ryan, C. R. (2002). Jordan in Transition: From Hussein to Abdullah. Lynne Rienner Publisher, Inc. United Kingdom.

Sanchez, V. (2018). Lights and Shadows of Jordan's Counterterrorism Strategy, Opinion Document, isee.es

Schwedler, J. (2012). The Politics of Protest in Jordan. Foreign Policy Institute Footnotes. The Newsletter of FPRI'S Watchman center, Philadelphia.

Tayem, F., \& Majali, R. (2018). The Arab Spring Crisis and the Democratic Trend in Jordan. Journal of Political and Law, 11(3).

The first article of Geneva Treaty concerning repression and terrorism prevention for the year 197.

The Jordanian Newspaper "AlRaia". (2014). An essay entitled Experts and politicians participation of Jordan in the Alliance against terrorism is a necessary step to protect the National Security. Retrieved from http://alraia.com/article/67960.html

Thiabat, K. (2015). Jordan Participation in the International Alliance to fight Dai'sh's organization. Journal of Strategic Visions.

UNDP. (2018). Support to Counterterrorism, Stabilization, and Counter radicalization in Jordan. Retrieved from www.jo.undp.org

\section{Copyrights}

Copyright for this article is retained by the author(s), with first publication rights granted to the journal.

This is an open-access article distributed under the terms and conditions of the Creative Commons Attribution license (http://creativecommons.org/licenses/by/4.0/). 